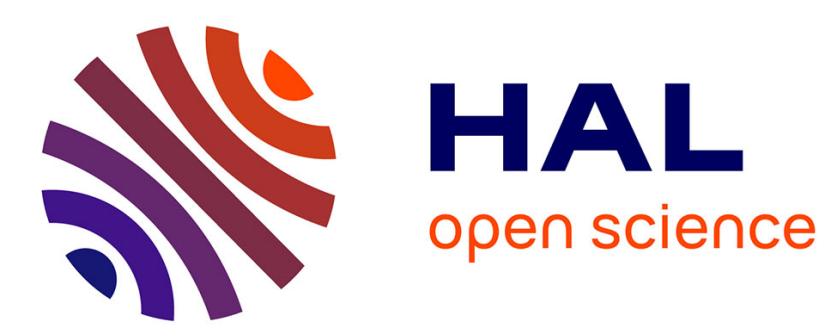

\title{
Improving take-up of health insurance program: a social experiment in France
}

Sophie Guthmuller, Florence Jusot, Jérôme Wittwer

\section{To cite this version:}

Sophie Guthmuller, Florence Jusot, Jérôme Wittwer. Improving take-up of health insurance program: a social experiment in France. Journal of Human Resources, 2014, 49 (1), pp.167-194. 10.3368/jhr.49.1.167 . hal-01523961

\section{HAL Id: hal-01523961 \\ https://hal.science/hal-01523961}

Submitted on 17 May 2017

HAL is a multi-disciplinary open access archive for the deposit and dissemination of scientific research documents, whether they are published or not. The documents may come from teaching and research institutions in France or abroad, or from public or private research centers.
L'archive ouverte pluridisciplinaire HAL, est destinée au dépôt et à la diffusion de documents scientifiques de niveau recherche, publiés ou non, émanant des établissements d'enseignement et de recherche français ou étrangers, des laboratoires publics ou privés. 


\section{ChaIre SÄNTÉ \\ UNE CHAIRE DE \\ LA FONDATION DU RISQUE}

\section{Cahiers de la Chaire Santé}

Improving take-up of health insurance program: a social experiment in France

Auteurs : Sophie Guthmuller, Florence Jusot, Jérôme Wittwer

$$
\text { N¹1 - Juin } 2012
$$




\title{
IMPROVING TAKE-UP OF HEALTH INSURANCE PROGRAM: \\ A SOCIAL EXPERIMENT IN FRANCE
}

\author{
Sophie Guthmuller ${ }^{\mathbf{1}}$, Florence Jusot ${ }^{\mathrm{ab}}$, Jérôme Wittwera \\ a PSL, Université Paris-Dauphine, Leda-Legos, Paris, France \\ ${ }^{b}$ Institute for Research and Information in Health Economics (IRDES), Paris, France
}

KEY WORDS: Subsidised health insurance; take-up; randomised experiment; uninsured; low-income population; France.

JEL CODES: C93, D81, I18, I38.

This paper was financially supported by the Haut Commissariat aux Solidarités actives contre la pauvreté (Ministère de la jeunesse et des solidarités actives) and by Health Chair, a joint initiative by PSL, Université Paris-Dauphine, ENSAE and MGEN under the aegis of the Fondation du Risque (FDR). Sophie Guthmuller thanks the Caisse Nationale d'Assurance Maladie des Travailleurs Salariés (CNAMTS) for the PhD scholarship.

The authors are grateful to the Caisse Primaire d'Assurance Maladie (CPAM) and to the Caisse d'Allocations Familliales (CAF) of Lille for their contribution to the experiment implementation and for their help in the data preparation.

The authors would like to thank Bruno Crépon, Tor Iversen, Andrew Clark, Peter Siminski and the participants of the $3^{\text {rd }}$ Australasian Workshop on Econometrics and Health Economics for their useful comments.

The authors declare that there are no conflicts of interest and that the procedures followed within the experiment were in accordance with the ethical standards of the CNIL (Commission Nationale de l'Informatique et des Libertés).

1 Correspondence to: Sophie Guthmuller, LEDa-LEGOS, Université Paris-Dauphine, Place du Maréchal de Lattre de Tassigny, 75775 Paris Cedex 16, France. Tel : +33 666835937 . Fax : +33 1440540 67. E-mail: sophie.guthmuller@dauphine.fr. 


\section{SUMMARY}

This paper is based on a randomised social experiment conducted in order to understand the low take-up rate of a Complementary health-insurance voucher program for the poorest in France (the Aide Complémentaire Santé: ACS). We explore two of the main hypotheses put forward to explain low enrolment: a lack of information about the program and a voucher amount considered to be too low. A sample of eligible individuals living in an urban area in Northern France were randomly split into three groups: a control group who benefited from the standard level of financial aid; a group benefiting from an increase in the value of the voucher; and a third group benefiting from the same increase along with an invitation to an information meeting regarding ACS. We show that the voucher increase has a small but statistically significant effect on ACS take-up. The invitation to the meeting appears to cancel out the positive effect of the voucher increase. Using an instrumental variable model to control for potential selection bias, we find ambiguous evidence of the meeting attendance on ACS take-up. This study confirms the difficulties that are faced in increasing the healthinsurance coverage of poor populations via subsidy programs. 


\section{INTRODUCTION}

The French Social Security system covers $76 \%$ of all health care expenditures. Individuals can purchase a complementary health insurance $(\mathrm{CHI})$ plan in order to reduce the remaining copayment. This system raises the issue of financial access to care and the affordability of $\mathrm{CHI}$ for the poorest populations. In France, as in other countries with health-care copayments, it has been widely reported that inequalities in access to health care are mainly explained by inequalities in access to CHI (Buchmueller et al., 2004; Doorslaer et al., 2004; Bago d'Uva and Jones, 2009; Or et al., 2009). Since these inequalities are considered to be unfair, public policies have been implemented in order to improve the coverage of low-income households by reducing the financial barriers which restrict their access to care.

In 2000, the French government instituted Complementary Universal Health Coverage (CMU-C), offering free CHI to the 7\% poorest households (Grignon et al., 2008). In 2005 a subsidised complementary-health-insurance program in the form of a voucher called an "Aide Complémentaire Santé" (ACS) was additionally introduced for poor households whose income was slightly above the CMU-C threshold. This program provides financial incentives for uninsured households to acquire a CHI plan. It also partially reimburses those who had already purchased a policy, and gives them an incentive to purchase a better-quality CHI plan. Currently only $6 \%$ of the French population does not have complementary insurance (Perronnin et al., 2011). However, 31\% of households whose resources are just above the CMU-C eligibility threshold still remain uninsured (Arnould and Vidal, 2008). This high rate of non-coverage amongst the poor is partly explained by the very low uptake of the ACS vouchers. In 2009 , this program was used by only $18 \%$ of the eligible population.

Two main hypotheses can be formulated to explain this low ACS uptake. The first is related to the lack of information regarding the program itself and the application process. This applies in particular to the eligible holders of an individual CHI who do not assert their 
rights. Recent literature reviews on the take-up of means-tested programs have shown that the non-pecuniary aspects of a program, such as stigma, transaction costs, administrative complexity and lack of information may strongly influence enrolment (Remler et al., 2001; Currie, 2006). A number of pieces of work have shown that information plays a role in takeup. Lo Sasso and Buchmueller (2004), for example, found that lack of information about the State Children's Health Insurance Program (SCHIP), partly due to little prior experience with public-insurance programs, may have contributed to nonparticipation. Daponte et al. (1998) showed that informing people about Food Stamp benefits increased enrolment. Similarly Aizer (2003) found positive effects of outreach, especially in the form of application assistance, on the take-up of Medicaid.

The second potential explanation of the globally low ACS take-up rate is insufficient subsidy. This may particularly be the case for eligible individuals who remain uncovered. The principal reason reported by individuals for being uninsured is indeed financial difficulties, which is consistent with previous work that has highlighted the predominant role of income in health-insurance demand in both France (Saliba and Ventelou, 2007; Grignon and KambiaChopin, 2009; Jusot et al., 2011) and the US (Marquis and Long, 1995; Thomas, 1995; Bundorf and Pauly, 2006; Auerbach and Ohri, 2006; Gruber, 2008). Before the deduction of the ACS voucher, these premia may represent nearly $10 \%$ of the income of the poorest households (Kambia-Chopin et al., 2008; Jusot et al., 2011). As the ACS voucher covers only $50 \%$ of the contract premium (Fonds CMU, 2008), the CHI may remain unaffordable for the poorest part of the eligible population even with the voucher: the subsidy may be insufficient to render the cost-benefit trade-off of being insured attractive. Last, the application process induces an additional cost which may not be entirely covered by the financial benefit of the voucher; this might explain the non take-up by eligible individuals who are already insured. 
This paper aims to test those two main explanations of low ACS take-up. The elasticity of ACS demand to the subsidy amount will be central. Several previous pieces of work have proposed inferring the expected impact of a subsidy on insurance demand based on estimates of the price elasticity of insurance demand in general population surveys in France (Franc and Perronnin, 2007; Grignon and Kambia-Chopin, 2009) or the US (Marquis and Long, 1995; Thomas, 1995; Marquis et al., 2004; Auerbach and Ohri, 2006). We here instead take a direct approach to public-policy evaluation by setting up a randomised social experiment to measure the effects of a change in the current subsidized CHI program on ACS take-up. We identify 4,209 individuals who are potentially eligible for ACS via their resources and randomly assign them into three groups which were offered different ACS voucher amounts and access to information. This experiment was implemented by a local office of the National Health Insurance Fund, called the Caisse Primaire d'Assurance Maladie (CPAM), in Lille, a large city in the North of France ${ }^{2}$.

The originality of our method should be underlined. Social experiments ensure the robust identification of the causal effects of public interventions. However, implementing a controlled social experiment is particularly costly and requires the active participation of the institutions involved. Very little work on health insurance has used randomised social experiments. One famous exception is the experiment carried out by RAND in the United States in the 1970s, which provided a wide variety of robust results regarding the link

\footnotetext{
${ }^{2}$ Lille' main urban subdivision had a population of 226,827 inhabitants while the metropolitan district has 1,105080 inhabitants, making it the 4 th most populous city in France. Lille is located in a former mining and industrial area. The unemployment rate of the 15-64 population is higher than the rate of the whole Metropolitan France (14.6\% versus $11.1 \%$ ), while the mortality rate is slightly lower than this of the whole Metropolitan France (7.7\%o versus $8.8 \%$ ).
} 
between health-insurance coverage and health-care expenditures and use (Manning et al., 1987). A randomised experiment on the same topic is currently being conducted in Oregon within Medicaid (Finkelstein et al., 2011). To the best of our knowledge, our social experiment is first to focus on the impact of subsidies and differentiated access to information on health-insurance demand.

The remainder of the paper is organised as follows. The design of the experiment and the data are described in Section 2. Section 3 then presents the results regarding the effect of the voucher amount and information briefing proposal on ACS take-up in the controlled experiment framework. The methods employed to evaluate the impact of participation in the information session and the ensuing results are detailed in Section 4. Finally, our findings are discussed in Section 5.

\section{THE DESIGN OF THE SOCIAL EXPERIMENT}

\subsection{Background}

The French health-insurance system consists of two parts: National Health Insurance (NHI) and complementary health insurance $(\mathrm{CHI})$. The National Health Insurance fund provides public, compulsory and universal health insurance which covers $76 \%$ of overall health expenditure, about $90 \%$ of inpatient care expenses, $65 \%$ of ambulatory-care expenses, but very little with respect to dental and eye care. However, individuals suffering from long-term illnesses benefit from full coverage of treatment costs related to their condition. This exemption from copayment does not however imply that these patients do not face relatively large out-of-pocket healthcare costs. For instance, they have to bear the copayments related to 
other illnesses they may have, but also any deductibles or charges which exceed the statutory $\mathrm{fee}^{3}$ for the expenditures related to their chronic disease (Elbaum, 2008).

The French NHI does not thus cover all health-care costs. The residual costs can be covered by a CHI policy. This $\mathrm{CHI}$ is additional, voluntary and private. In France, $\mathrm{CHI}$ is not only complementary to NHI, as CHI covers co-payments, but also supplements NHI as it can reimburse charges which exceed the statutory fee or health-care expenses which are not covered at all by NHI (for instance, excess fees for doctor visits, non-reimbursed medication and private rooms in hospital). CHI contracts can be purchased either individually or through the individual's employer. Starting in 2000 , a free and public complementary health insurance, called CMU-C, has been available for low-income individuals, which pays for most out-ofpocket expenses. The CMU-C program covers $7 \%$ of French population (Arnould and Vidal, 2008).

2005 saw the introduction of a subsidized complementary-health-insurance program in the form of a voucher called the "Aide Complémentaire Santé" (ACS) for poor households whose income was slightly above the CMU-C threshold. In January 2009, households whose income level was between the CMU-C threshold and $20 \%$ over this threshold were eligible for ACS: it thus applied to households with an annual income between $€ 7,447$ and $€ 8,936$ per consumption unit. ${ }^{4}$ In practice, eligible households can apply for ACS at their local National

\footnotetext{
${ }^{3}$ In France, healthcare fees are agreed by the National health insurance system and reimbursement is based on these statutory fees. However, some doctors (those belonging to the unregulated payment sector) have the right to set prices exceeding this statutory fee for their visits or for a certain type of care. This was the case for $24 \%$ of all physicians in 2010 . This rate is $41 \%$ in average for specialists care but varies by specialty. For instance, $85 \%$ of the surgeons has the right to ask for higher fees while this figure is $32 \%$ for paediatricians (Cnamts, 2011).

${ }^{4}$ From January 2011, ACS covered individuals with resources up to $26 \%$ above the CMU-C plan eligibility threshold. This figure will be extended to 30\% in 2012 (PLFSS, 2011).
} 
Health Insurance office to benefit from the voucher which is subtracted from the price of the insurance plan. This voucher is only valid for individual plans, and does not apply to employer-provided plans.

The voucher amounts depend on the number of beneficiaries and their age, ranging from $100 €$ to $400 €$ per individual ${ }^{5}$. Table I shows the voucher amounts in 2009 , when the experiment was implemented. According to the CMU, the average annual cost of a CHI plan taken out by ACS beneficiaries was $764 €$ in 2009 (Fonds CMU, 2010). The voucher hence represents on average $50 \%$ of the annual $\mathrm{CHI}$ premium.

[Insert Table I about Here]

\subsection{The Design}

The experiment was jointly designed with the CPAM of Lille based on its previous practice. Up to 2009 , the CPAM offered a specific service only to individuals who applied for the CMU-C but who were in fact eligible for ACS. These individuals were invited to an information briefing session and were proposed an increased voucher amount funded locally by the CPAM. Based on this existing practice, our social experiment was designed to test the impact of a general increase in the ACS subsidy and improved access to information in the form of a briefing session on ACS take-up amongst the entire eligible population for ACS.

The experiment relied on the national postal information campaign launched to inform individuals about the ACS scheme, organised at a local level by each CPAM. All potentially eligible individuals covered by the CPAM in Lille were identified at the end of 2008 on the

\footnotetext{
${ }^{5}$ The voucher amounts have been revised upwards, and new age brackets were defined in August 2009: under 16 years old $=100 € ; 16-49$ years old $=200 € ; 50-59$ years old $=350 € ;$ and 60 and over $=$ $500 €$.
} 
basis of their 2007 tax declarations which entitled them to family allowance benefits from the Lille Family Benefits Fund (CAF) in $2008^{6}$. The computer search used to select the population potentially eligible for the ACS was originally conceived by the Grenoble Observatory on the non take-up of social rights and public services (ODENORE) (Revil, 2008). 4,209 individuals were randomly selected to participate in the experiment amongst the individuals who were potentially eligible for ACS and who had not taken up their rights at the end of $2008 .^{7}$

\footnotetext{
${ }^{6}$ In French, CAF stands for "Caisse d'allocations familiales". The CAF offers allowances related to family, children, housing, and the minimum income. Allowances entitlement and amounts are
} conditional on household income. It is important to note that using the mailing lists of the CAF to identify those potentially eligible for the ACS restricts the analysis to people entitled to the allowances offered by the CAF. Without being able to give a specific figure, it is likely that the selected sample is broadly representative of the eligible population. Nevertheless, we have selected a population who already use social security. This means that we remove from the analysis households who are eligible for ACS but systematically do not take up social benefits, and households who are eligible for the ACS but not for family allowances (for instance, elderly home owners).

${ }^{7}$ Originally, 5,000 individuals were identified. However, it should be kept in mind that ACS eligibility is evaluated in terms of household resources, and the program itself is a benefit attributed to the household. Moreover, some households (dual-earner couples in particular) are composed of several individuals identified by CAF as potentially eligible. During the information campaign the letters were sent by the CPAM to each individual; some households consequently received several letters. In our experimental setting, these cases are problematic. Two individuals who were randomly assigned into different groups but who belong to the same household may have received two different letters. To address this contamination bias, we removed from our sample all individuals belonging to the same household but assigned to different groups. In addition, we randomly selected an individual within households in which several individuals were assigned to the same group. Accordingly, dual-earner 
This experimental population was randomly divided into three groups. In January 2009, 1,394 individuals assigned to the control group received a letter by post informing them of the National ACS scheme in force on that date; 1,412 individuals in the first treatment group received the same letter but stipulating an increase in the voucher amount; and 1,403 individuals in the second treatment group received by post the same letter stipulating the increased voucher amount and a second letter with an invitation to an information briefing. An ACS application form that potentially eligible individuals were invited to return for effective eligibility assessment was enclosed in all of the letters. The files provided by CAF only allowed us to target the population who were likely eligible for the ACS without guaranteeing their effective eligibility since, as noted above, the CAF files were based on 2007 income levels whereas ACS eligibility is based on income twelve months prior to application.

The voucher increase proposed to treatment groups 1 and 2 represented a $62.5 \%$ to $75 \%$ increase over the national subsidy in force according to age. The financial aid proposed per person to each age group is shown in Table II. ${ }^{8}$

\section{[Insert Table II about Here]}

The information meeting on the ACS proposed to treatment group 2 and led by a social worker was conducted in groups and took place at the CPAM head office in Lille. These briefings were aimed at informing individuals about the ACS scheme and the formalities

\footnotetext{
couples are generally but identically under-represented in each group. The final sample covers 4,209 individuals.

${ }^{8}$ The increased vouchers are only temporary: they last two years and the voucher amount is cut in half the second year.
} 
required to benefit from it. The meeting was not restricted to individuals who had returned an application form. Twelve briefings were organized from February to April 2009, at a rhythm of two per week on Thursday and Saturday mornings. This is why letters to the second treatment group were sent out in successive waves over a two-month period so as to manage the flow of individuals who responded positively to the meeting invitation.

\subsection{Experimental data matched with administrative data}

The returned application forms and ACS agreements were observed between January 21st (the date at which the first wave of letters was sent out) and July 30th 2009 (the experimental end date) by the CPAM benefits department. The data collected by the CPAM provides information on each individual included in the experimental sample: the experimental group; whether an ACS application form was returned; if after assessment they were notified of their entitlement to ACS; in the case of refusal, whether it was due to above-threshold resources or on the contrary below-threshold resources entitling them to CMU-C. Finally, for individuals in treatment group 2, information on briefing attendance was recorded.

These data were then matched to CPAM administrative data containing information on age, gender, whether if individuals were within the working population or out of the labour force due to disability or to retirement on 31st December 2008 long-term illness scheme beneficiaries, ambulatory-care expenditures in 2008, CHI status prior to the experiment and CMU-C beneficiaries in 2007. Table A1 in Appendix A presents the full set of variables used. Information on inpatient care expenditure is not available, since these are not individually recorded by CPAM due to the specific financing system of hospitals. Not taking these expenditures into account in the analysis does not much affect the willingness to buy a CHI, as CHI mostly covers ambulatory-care expenditure and inpatient care is almost entirely covered by National Health Insurance. 
Information on $\mathrm{CHI}$ plan status is collected by the CPAM thanks to a computer information exchange standard called NOEMIE (Norme Ouverte d'Echange entre Maladie et les Intervenants Exterieurs). This standard allows the electronic transmission of healthcare invoices between CPAM offices and CHI providers. Note however that not all CHI providers are affiliated to NOEMIE, which leads, in our data, to an underestimation of the rate of CHI coverage. Moreover, data on CHI coverage recorded via National Health Insurance does not tell us if the CHI was purchased through the employer or individually. Since individuals covered by an employer-provided CHI are actually not eligible for ACS, independently of their income level, this lack of information can induce an overestimation of the eligible population. However, we expect this bias to be limited as employer-provided CHIs are rare for low-wage workers.

Table III provides descriptive statistics for the population under consideration. We check that the random assignment did indeed lead to very similar distributions of variables between groups. ${ }^{9}$ The sample is equally split between men and women. A large proportion, almost $80 \%$, is aged 25 to 59 while the under-25s represent less than $10 \%$ of each group. Regarding the employment status, $61 \%$ are in the working population, nearly $25 \%$ are out of the labour market due to disability and $15 \%$ receive a retirement pension. Finally, we note that one month before the start of the experiment, one individual out of three was not covered by a CHI plan, ${ }^{10}$ while $50 \%$ of the population had ambulatory healthcare expenditures greater than $700 €$ in 2008.

\footnotetext{
${ }^{9}$ Chi-square tests accept the null hypothesis of independence.

${ }^{10}$ This rate is well above survey-data estimates for this population (this rate being $19 \%$ if the population is approximated by the first income decile and $14 \%$ for the second decile (Arnould and Vidal, 2008)). The gradual adoption of the standard exchange system NOEMIE certainly explains part of the difference: not all CHI providers were affiliated to the system in December 2008.
} 
[Insert Table III about Here]

\section{METHODOLOGY AND RESULTS OF THE RANDOMISED TREATMENTS}

\subsection{Methodology}

The evaluation of the effect of the voucher increase and the information meeting on the demand for ACS is theoretically based on the potential-outcome model, developed by Roy (1951) and Rubin (1974). More formally, we want to estimate the causal effect of a treatment $\mathrm{T}$ on an outcome $\mathrm{Y}$. This model defines two potential outcomes, $Y_{i 1}$ the outcome of individual $i$ when $i$ is treated and $Y_{i 0}$ the outcome of individual $i$ when $i$ is untreated. The causal effect of participating in the treatment for $i$ is then $\Delta_{i}=Y_{i 1}-Y_{i 0}$. But $\Delta_{i}$ is always unobservable as only one of the outcome variables is observable: when $i$ is treated, $Y_{i 1}$ is realized and $Y_{i 0}$ is not observed. $Y_{i 0}$ is then called the counterfactual outcome and refers to the outcome $\mathrm{Y}$ that would have pertained had the individual been treated.

More precisely, we want to measure the average treatment effect (ATE) on the full population. $\Delta_{A T E}=E\left[Y_{1}-Y_{0}\right]=E\left[Y_{1}\right]-E\left[Y_{0}\right]$. As the counterfactual is unobservable, our aim is to find the best substitute in order to estimate the ATE without bias.

Within the framework of an experimental design, the treatment is randomly assigned across individuals: untreated individuals form the control group and treated individuals the treatment group. Thus if the sample of individuals is sufficiently large, random assignment ensures that both groups are similar, not only with respect to observable variables but also unobservable variables. This solves the self-selection issue by construction. Formally we have, $E\left[Y_{0} \backslash T=1\right]=E\left[Y_{0} \backslash T=0\right]=E\left[Y_{0}\right]$ and $E\left[Y_{1} \backslash T=1\right]=E\left[Y_{1} \backslash T=0\right]=E\left[Y_{1}\right]$.

In our social experiment we defined two different treatments: an ACS voucher increase for the first treatment group and an information meeting proposal in addition to the voucher increase for the second treatment group. As these treatments were randomly assigned, evaluation is primarily based on a quantitative review of returned application forms, ACS 
proposals and refusals in the different groups. The impact of the treatments can then be estimated by difference in the means between the treated and untreated groups. The effect of the voucher increase will then be estimated by the difference in the means between treatment group 1 and the control group, and that of the meeting proposal by the difference in the means of the outcome variable between treatment group 2 and treatment group 1. Significant differences between groups are evaluated via Chi-squared tests.

We focus on two outcome variables to evaluate treatment effectiveness: the rate of returned application forms and the rate of ACS notified, i.e. the proportion of experienced individuals who effectively received an ACS voucher after eligibility re-assessment by the CPAM.

\subsection{Impact of the voucher increase}

We assess the demand for or the interest in the ACS by the number of returned application forms subsequent to the letter received from the CPAM. Of the 4,209 individuals involved, only 701 returned an application form for a take-up rate of $16.7 \%$ (see Table IV). Table IV also compares the application return rates by group. $15.9 \%$ of the control group returned a completed ACS application form (222 applications). The take-up rate in treatment group 1, who benefitted from the increased voucher amount, is higher (at the 5\% significance level) than that in the control group with $18.6 \%$ of applications. Increasing financial aid thus appears to have a positive, though limited, impact on the probability of take-up.

\section{[Insert Table IV about Here]}

This impact can be measured by the elasticity of the probability of returning a completed application form to the financial aid proposed. This elasticity is calculated by the ratio of the 
rise in the probability of returned forms to the rise in the voucher amount ${ }^{11}$, and is equal to 0.22 (see Table V). Surprisingly, the results are quite similar for individuals already covered by CHI (66.2\% of the sample) and those who are not $(33.8 \%)$. The rate of returned applications among individuals already covered by $\mathrm{CHI}$ is $16.4 \%$ in the control group and $19 \%$ in treatment group 1 , as against $15 \%$ and $17.6 \%$ respectively among individuals without CHI coverage: these differences are not significant. Similarly, we observe no difference in the elasticity of take-up rate to voucher amount according to $\mathrm{CHI}$ coverage ( 0.23 for individuals initially covered by $\mathrm{CHI}$ as against 0.21 for those not covered).

\section{[Insert Table V about Here]}

Beyond the rate of completed application forms, and within the experimental framework, we can also calculate the percentage of individuals effectively entitled to ACS, since a number of the applications were refused. The ACS agreements are presented in Table VI and the cases of ACS refusal in Table VII. In total, 55.2\% of returned applications were in fact eligible for ACS (see Table VI), 10.1\% were eligible for CMU-C but not ACS (in the cases where income was below the minimum ACS threshold) and $34.7 \%$ were refused because their income levels were too high. Among the 4,209 individuals included in the experiment, 9.2\% were effectively eligible for ACS, $1.7 \%$ for CMU-C, 5.8\% was refused both ACS and CMUC, and $83.3 \%$ failed to apply (see Table VI and Table VII).

\section{[Insert Table VI about Here]}

\footnotetext{
${ }^{11}$ By using a growth rate of $75 \%$ for the voucher amount (although this figure is $62.5 \%$ for the over60s), we choose to underestimate the aggregate elasticity rather than estimate the elasticity separately by age group with limited accuracy due to the small number of individuals over 60 .
} 


\section{[Insert Table VII about Here]}

A comparison of the number of ACS agreements by group yields similar results to those obtained for the comparison between returned applications. However, the gap between the control group and treatment group 1 is accentuated. The rate of ACS agreements relative to the number of participants is $10.8 \%$ in treatment group 1 as against $7.9 \%$ in the control group. Similarly, the number of ACS agreements in relation to the number of completed applications is $58 \%$ in treatment group 1 compared to only $49.6 \%$ in the control group (see Table VI). The exceptional financial aid offered to the individuals in treatment groups 1 and 2 appears to have more successfully targeted eligible beneficiaries, that is to say the poorest individuals in the experimental sample, since the rate of refusals due to income levels above the eligibility threshold is much lower in treatment groups 1 and 2 than in the control group (see Table VII).

\subsection{Impact of the proposed meeting}

The rate of returned applications is $15.5 \%$ among treatment group 2, whose members received an invitation to an information briefing as well as a voucher increase. This rate is slightly lower than that in the control group, but not significantly so. On the contrary, the rate is significantly lower in treatment group 2 than in treatment group 1 (at the $5 \%$ significance level). Somewhat unexpectedly, the invitation to the briefing appears to have impeded takeup, thus cancelling out the positive effect of the voucher increase.

Among the 1,403 individuals in treatment group 2, only 125 attended the information briefing to which they were invited (8.9\%). Of these, 35 completed and returned an ACS application form. The take-up rate is $28 \%$ of the individuals who attended the briefing. On the contrary, among the 1,278 individuals in treatment group 2 who did not attend the briefing, the take-up rate is only $14.2 \%$. 
These results could lead to the conclusion that, on the one hand, the information briefing had a positive impact on the ACS take-up rate amongst those who participated and, on the other, a negative effect for those who failed to attend the briefing. One explanation could be that some of the individuals in the second treatment group, those who did not go to the meeting, thought that meeting attendance was compulsory and therefore did not consider it a good thing to apply for the ACS since they could not attend the meeting (this result remains significant after controlling for covariates, see Table B1 in Appendix B).

\subsection{Impact of covariates}

In order to look at the impact of covariates on the probability to complete application forms we run a probit regression on the whole sample (see Table VIII). First, the important thing to note is that these estimations confirm the slight positive effect of the voucher increase and the deleterious effect of the meeting invitation within the experimental results. The average marginal effects are similar to the differences of the rate of returned forms between groups obtained in Table IV.

Besides, it is very clear that high healthcare expenditures expectation increases the probability of ACS take-up. It appears indeed that age and previous healthcare expenditures (in 2008) have significant and big impacts. Similarly, the effect of disability is certainly linked to healthcare needs. It is finally worth noting that the people's response to information on ACS benefits is mainly explained by healthcare needs while the role of economic incentives, as the voucher increase, appears to be much weaker. One can imagine that people with high healthcare needs are simply much more aware of any public program for healthcare benefits.

Last, the roles of gender and retirement may be noticed. The effect of retirement is likely explained by the time that retired people can devote to ACS take-up. The role of gender is 
more difficult to analyse. One possible explanation is the expected high proportion of single mothers in our sample. It is indeed difficult for single mothers to deal with the heavy administration process associated with ACS take-up.

\section{[Insert Table VIII about Here]}

\section{IMPACT OF MEETING ATTENDANCE}

As indicated above, individuals who attended the meeting are significantly more likely to complete an application form (and to obtain an ACS agreement). This result needs to be looked at more carefully as we can no longer rely on the experimental nature of our data at this point.

\subsection{Methodology}

As can be seen in the results in Table IV, the impact of the meeting proposal on ACS take-up is ambiguous. It seems to be positive for people who attended but negative for those who did not. This result raises the question of how to disentangle the "invitation" from the "participation" effect amongst individuals in the second treatment group.

As meeting attendance was not compulsory, it is likely that individuals self-selected themselves, i.e. individuals with a positive expected outcome were more likely to participate. In order to control for potential endogeneity bias we employ the following strategy. We estimate the probability $\mathrm{Y}$ of returning an application form using a 2 stage least square (2SLS) model.

In the first stage, the predicted probability of attending the meeting (MA) is estimated using a linear probability model as follows:

$$
M A_{i}=a+b * \text { TravelTime }_{i}+c * Z_{i}+V_{i}
$$


Where $Z_{i}$ is a set of prior individual characteristics, $V_{i}$ the error component and TravelTime $_{i}$ an instrumental variable. Theoretically, the distance from home to the CPAM office should have a direct and significant effect on the probability of attendance, but not on the likelihood of returning an application form. ${ }^{12}$ The travel time by car in minutes TravelTime $_{i}{ }^{13}$ is empirically valid ${ }^{14}$ and is used as instrumental variable in the regression.

The predicted probabilities are then used in a second stage regression to explain variation in the probability $\mathrm{Y}$ of returning an application form.

Based on this model, we run a Durbin-Wu-Hausman test (Durbin, 1954; Wu, 1974; Hausman, 1978) in order to test whether the meeting attendance variable is endogenous and we check whether the instrument is weak by computing the F statistic for joint significance of the instrument in the first stage regression of MA on the instrument $\left(\right.$ TravelTime $\left._{i}\right)$ and the covariates $\left(Z_{i}\right)$. See Appendix C.

\subsection{Impact of the briefing attendance}

Table C1 in Appendix C displays the estimates of the 2SLS Model presented earlier and of an Instrumental variable (IV) probit model considering the binary nature of the probability of

\footnotetext{
${ }^{12}$ Alternatively, we could have used assignment to the first treatment group as an instrument and estimate a local average treatment effect. However, in our case, assignment to the first treatment group is not a valid instrument because the meeting proposal has a negative and significant impact on the probability of applying for ACS.

${ }^{13}$ TravelTime was build with the itinerary tool of Mappy.com using the postal address of each individual and the postal address of the CPAM office.

${ }^{14}$ The coefficient is not significantly different from zero in the probit regression: $Y_{i}=f+g *$ TravelTime $_{i}+h * Z_{i}+i * M A+W_{i}$. with a p-value equals to 0.266 . $^{2}$
} 
returning an application form $\mathrm{Y}$. The meeting attendance variable does not appear to be endogenous given the result of the Hausman test. The null hypothesis of exogeneity cannot be rejected; the p-value equals 0.385 for the 2 SLS Model and is 0.487 for the IV-probit.

Since we cannot reject the exogeneity of the meeting attendance variable, we prefer to comment and to rely on the results of the simple probit regression presented in Table IX which gives a convergent and more precise estimate of meeting attendance (MA). MA seems to have a positive and significant impact on ACS take-up. After controlling by covariates, the average marginal effect is 0.118 and is slightly lower than the estimate in the experimental result (0.137).

\section{[Insert Table IX about Here]}

However, this result should be interpreted with cautious. The exogeneity of the meeting attendance variable is not rejected but the instrument we use is suspected to be weak as the Fstatistic of the significance of the instrument in the first stage regression is 8.32. Staiger and Stock (1997) show that the F statistic should be greater than 10 in order to completely rule out the problem of weak instrument. Moreover, the small number of people who attended the meeting does lead to a notable lack of statistical power in the estimates. It is then unlikely that we would reject the null hypothesis of exogeneity, and thus we cannot conclude as to the existence of a causal effect of meeting attendance.

\section{DISCUSSION}

This experiment has shown that increasing the voucher amount slightly improves the ACS take-up rate, with an elasticity of the probability of applying for ACS to the subsidy of 0.22 . These results are consistent with previous work in the US showing a price elasticity of health 
insurance demand varying between -0.2 and -0.6. This work also suggests a weak but significantly positive effect of a subsidy on health-insurance demand (Thomas, 1995; Marquis and Long, 1995; Marquis et al,. 2004; Auerbach and Ohri, 2006).

The weakness of this impact hence suggests that the core reason behind the poor take-up rate is not the cost of complementary health insurance but more the lack of access to information concerning the scheme and the complexity of the application process, consistent with recent literature reviews on the take-up of means-tested programs (Remler et al., 2001; Currie, 2006). Thus, this social experiment notably demonstrates the difficulty of setting up an information campaign regarding the ACS scheme that, in the end, fails to reach its target population. Despite the postal information campaign targeting all individuals potentially eligible for ACS, less than one out of five individuals returned a completed application form (16.7\% return rate). Another troubling result is that application return rates and individuals' sensitivity to the amount of financial aid proposed are very similar among individuals initially covered by a CHI and uncovered individuals. However, ACS is presented as a windfall for those who have already purchased a CHI contract and from whom one could have expected a massive take-up rate, especially with the voucher increase. Recall that individuals covered by an employer-provided group contract are not eligible for ACS. However, according to Arnould and Vidal (2008), only $14.5 \%$ of households whose resources are just above the CMU-C eligibility threshold benefit from employer-provided plans, whereas $34 \%$ of the French population benefit from employer-provided plans. Therefore, this ineligibility criterion cannot alone explain the massive non-take-up of people initially covered.

Moreover, within treatment group 2, only $8.9 \%$ of the individuals invited to the briefing actually participated. These results immediately question the number of letters that actually reached the individuals concerned. The actual figure is unknown but a percentage of undelivered letters due to address change is another possible explanation, especially since 
mobility is closely correlated to precarity. Nevertheless, the use of administrative data guarantees the quality of the addresses since those addresses were actually used by the administration for correspondence.

This experiment also shows that the invitation to participate in an information briefing discouraged certain individuals from applying. This illustrates the difficulty in adequately communicating the existence of a scheme and the administrative procedures involved in order to benefit from it. This certainly legitimizes the idea of using third-party organizations (associations, mutual benefit organizations, social workers etc.) to diffuse information and support (Chauveaud and Warin, 2009).

Finally, this experiment underlines the difficulties in effectively reaching the targeted population. In total, only $55.2 \%$ of the individuals who applied for ACS were effectively eligible for this program and received an ACS agreement. The refusal rate is inordinately high for a preselected population and underlines the complexity of eligibility criteria and the narrowness of the target population. This is an essential factor to take into account, since uncertainty over effective eligibility reduces the incentive to apply for the program. Our results suggest that health insurance subsidy could help to better target eligible populations, since the acceptance rate is slightly higher in both treatment groups than in the control group (58\% versus $50 \%$ ). In particular, the proportion of refusals due to resources above the eligibility threshold was lower in both treatment groups, suggesting that the increase in the subsidy has above all attracted the poorest amongst the experimental sample.

The experimental approach used in this study has the advantage of relying on the assessment of a program implemented in vivo and therefore avoids selection issues that are usually the main difficulty in evaluating public policy. However, the gain in internal validity is counterbalanced by a loss in external validity. The population studied here is only representative of the eligible population for ACS in Lille, which undoubtedly has its own 
particular characteristics. Nevertheless, Lille is the 4th biggest city in France and is characterised by a high unemployment rate. We can then suppose that the population of Lille is quite representative of the French low income population. Similarly, the effectiveness of the experiment is dependent on the institution that conducted it and the relationship it has with the individuals concerned. Nothing guarantees that the same experiment conducted with a similar population would have given the same results in another CPAM. Moreover, as with all experiments, it is limited in time. It does not allow us to observe the eventual long-term repercussions of increasing the voucher amount associated with the slow diffusion of information. In the end, receiving an ACS agreement does not necessary mean using it to purchase CHI coverage. It would therefore be of interest, in future work, to examine the effects of the treatments on CHI coverage.

This experiment has provided some relevant elements for improving access to health insurance of the low-income population in France. Considering that increasing the voucher amount slightly improves the ACS take-up rate and better targets the eligible population, we may expect that the increase in the standard amount of financial aid for individuals aged 50 and over instituted on January 1st 2010 will have a positive impact on ACS take-up. However, as this national increase is lower than that proposed within the framework of our experiment, we can also expect the impact to be smaller. Moreover, this experiment points out the difficulty of reaching a target population by means of a postal information campaign, such as that implemented at the national level in 2008-2009, and the counter-productive nature of the invitation to an information briefing. In this light, extending the target population on January 1st 2011 may be a first step to encouraging ACS take-up. Nevertheless, these changes to the ACS program may well be insufficient to generalize access to health insurance for the poorest, and further research is needed to properly design other forms of intervention or alternative policies. 


\section{REFERENCES}

Arnould ML, Vidal G. 2008. Typologie des contrats les plus souscrits auprès des complémentaires en 2006. Etudes et Résultats 663.

Auerbach D, Ohri S. 2006. Price and Demand for Non-Group Health Insurance. Inquiry 43(2): 122-134.

Aizer A. 2003. Low Take-Up in Medicaid: Does Outreach Matter and for Whom? American Economic Review Papers and Proceedings 93(2):238-41.

Bago d'Uva T, and Jones AM. 2009. Health care utilisation in Europe: new evidence from the ECHP. Journal of Health Economics 28(2): 265-279.

Buchmueller TC, Couffinhal A, Grignon M, Perronnin M. 2004. Access to physician services: does supplemental insurance matter? Evidence from France. Health Economics 13(7): $669-687$.

Bundorf MK, Pauly MV. 2006. Is health insurance affordable for the uninsured? Journal of Health Economics 25(4): 650-673.

Chauveaud C, Warin P. 2009. Favoriser l'accès aux soins des bénéficiaires de minima sociaux. Expliquer la CMU-C et l'ACS aux populations potentiellement éligibles. Odenore collection Etude 32.

Cnamts. 2011. Médecins exerçant en secteur 2: une progression continue des dépassements

d'honoraires, la nécessité d'une réforme structurelle du système. Point d'information [17 mai 2011]

Currie J. 2006. The take-up of social benefits. In Auerbach, Alan J., David Card, and John M. Quigley (Eds.), Poverty, the distribution of income, and public policy: 80-148. New York: Russell Sage.

Daponte BO, Sanders S, Taylor L. 1998. Why Do Low-Income Households Not Use Food Stamps? Evidence from an Experiment. Journal of Human Resources 34(3): 612-28. 
van Doorslaer E, Koolman X, Jones AM. 2004. Explaining income-related inequalities in doctor utilisation in Europe. Health Economics 13(7): 629-647.

Durbin J. 1954. Errors in Variables. Review of the International Statistical Institute 22(1/3) $: 23-32$

Elbaum M. 2008. Participation financière des patients et équilibre de l'Assurance maladie. Lettre de l'OFCE 301.

Finkelstein A, Taubman S, Wright B, Bernstein M, Gruber J, Newhouse JP, Allen H, Baicker K, The Oregon Health Study Group. 2011. The Oregon Health Insurance Experiment: Evidence from the First Year. NBER Working Paper 17190.

Fonds CMU. 2008. L'aide à la complémentaire santé en 2007. Rapport du Fonds CMU au Gouvernement sur l'évolution du prix et du contenu des contrats ayant ouvert droit à l'aide complémentaire santé en 2007 (en application de l'article L.863-5 du Code de la Sécurité Sociale) [Juin 2008].

Fonds CMU. 2010. L'aide à la complémentaire santé en 2009. Rapport du Fonds CMU au Gouvernement sur l'évolution du prix et du contenu des contrats ayant ouvert droit à l'aide complémentaire santé en 2009 (en application de l'article L.863-5 du Code de la Sécurité Sociale) [Juin 2010].

Franc C, Perronnin M. 2007. Helping the poor to acquire a complementary health insurance: an initial appraisal of the ACS system. Issues in Health Economics (Questions d'économie de la santé). Irdes 121.

Grignon M, Perronnin M, Lavis JN. 2008. Does free complementary health insurance help the poor to access health care? Evidence from France. Health Economics 17(2): 203-219.

Grignon M, Kambia-Chopin B. 2009. Income and the Demand for Complementary Health Insurance in France. Irdes Document de travail 24. 
Gruber J. 2008. Covering the Uninsured in the United States. Journal of Economic Literature 46(3):571-606.

Hausman JA. 1978. Specification Tests in Econometrics. Econometrica, 46 (6): 1251-71.

Jusot F, Perraudin C, Wittwer J. 2011. Les déterminants des dépenses de la complémentaire santé en France: les résultats de l'enquête budget de famille 2006. Document de travail LEDa-LEGOS, forthcoming online: http://www.legos.dauphine.fr/.

Kambia-Chopin B, Perronnin M, Pierre A, Rochereau T. 2008. Complementary Health Insurance in France in 2006: Access is Still Unequal. Issues in Health Economics (Questions d'économie de la santé). Irdes 132.

Lo Sasso AT, Buchmueller TC. 2004. The effect of the state children's health insurance program on health insurance coverage. Journal of Health Economics 23(5): 1059-1082.

Manning WG, Newhouse JP, Duan N, Keeler EB, Leibowitz A, Marquis AM. 1987. Health Insurance and the Demand for Medical Care: Evidence from a Randomized Experiment.”American Economic Review 77(3): 251-277.

Marquis MS, Long SH. 1995. Worker Demand for Health Insurance in the Non-Group Market. Journal of Health Economics 14(1): 47-63.

Marquis S, Beeuwkes Buntin M, Escarce JJ, Kapur K, Yegian JM. 2004. Subsidies and the Demand for Individual Health Insurance in California. Health Services Research 39(5): $1547-1570$.

Or Z, Jusot F, Yilmaz E, The European Union Working Group on Socioeconomic Inequalities in Health. 2009. Inégalités sociales de recours aux soins en Europe: Quel rôle pour le système de soins ? Revue Economique 60(2): 521-543.

Perronnin M, Pierre A, Rochereau T. 2011. Complementary Health Insurance in France: Wide-Scale Diffusion but Inequalities of Access Persist. Issues in Health Economics (Questions d'économie de la santé). Irdes 161. 
PLFSS. 2011. Projet de loi de financement de la sécurité sociale pour 2011. http://www.securite-sociale.fr/chiffres/lfss/lfss2011/2011_plfss.pdf.

Remler DK, Rachlin JE, Glied SA. 2001. What can the take-up of other programs teach us about how to improve take-up of health insurance programs? NBER Working Paper $\mathbf{8 1 8 5}$.

Revil H. 2008. Identifier des populations en non-recours aux dispositifs de l'Assurance maladie: proposition de méthode. Recherches et Prévisions 93: 102-109.

Roy AD. 1951. Some Thoughts on the Distribution of Earnings. Oxford Economic Papers, New Series 3(2):135-146.

Rubin DB. 1974. Estimating causal effects of treatments in randomized and nonrandomized studies. Journal of Educational Psychology 66(5):688-701.

Saliba B, Ventelou B. 2007. Complementary health insurance in France: Who pays? Why? Who will suffer from public disengagement? Health Policy 81(2): 166-182.

Staiger D, Stock, JH. 1997. Instrument Variables Regression with Weak Instruments. Econometrica 65(3) : 557-586.

Thomas K. 1995. Are subsidies enough to encourage the uninsured to purchase health insurance? An analysis of underlying behavior. Inquiry 31(4): 415-424.

WU DM. 1974. Alternative tests of independence between stochastic regressors and disturbances: Finite sample results. Econometrica 42(3) : 529-546. 


\section{APPENDIX A}

Table A1. Description of variable set

\begin{tabular}{|c|c|c|}
\hline Type & Variables & Description \\
\hline \multirow{6}{*}{$\begin{array}{l}\text { Experimental } \\
\text { data }\end{array}$} & $\begin{array}{l}\text { Completed form } \\
\text { returned }\end{array}$ & $\begin{array}{l}\text { Dummy variable }=1 \text { if individual returned completed } \\
\text { application form, } 0 \text { otherwise }\end{array}$ \\
\hline & ACS proposal & $\begin{array}{l}\text { Dummy variable }=1 \text { if individual received an ACS } \\
\text { proposal after CPAM assessment, } 0 \text { otherwise }\end{array}$ \\
\hline & CMU-C proposal & $\begin{array}{l}\text { Dummy variable }=1 \text { if individual received an ACS refusal } \\
\text { but a CMU-C proposal (in case of resources below ACS } \\
\text { eligibility threshold) after CPAM assessment }\end{array}$ \\
\hline & ACS refusal & $\begin{array}{l}\text { Dummy variable }=1 \text { if individual received an ACS and } \\
\text { CMU-C refusal (in case of resources above ACS } \\
\text { eligibility cap) after CPAM assessment, } 0 \text { otherwise }\end{array}$ \\
\hline & Meeting participation & $\begin{array}{l}\text { Dummy variable }=1 \text { if individual went to the meeting, } 0 \\
\text { otherwise (only for treatment group 2) }\end{array}$ \\
\hline & Travel time & $\begin{array}{l}\text { Travel time in minutes from home to the CPAM head } \\
\text { office (for each individual). }\end{array}$ \\
\hline \multirow{3}{*}{$\begin{array}{l}\text { Socio- } \\
\text { demographic } \\
\text { variables }\end{array}$} & Age in 2008 & Individual \\
\hline & $\mathrm{Age}^{2}$ in 2008 & Individual \\
\hline & Gender & Individual \\
\hline \multirow{6}{*}{$\begin{array}{l}\text { Health, } \\
\text { Health care } \\
\text { utilisation } \\
\text { and } \mathrm{CHI} \\
\text { coverage }\end{array}$} & $\begin{array}{l}\text { Health care } \\
\text { expenditures in } 2008\end{array}$ & $\begin{array}{l}0 €-199 € \\
200 €-699 € \\
700 €-1,999 € \\
>=2,000 €\end{array}$ \\
\hline & $\begin{array}{l}\text { Long-term diseases } \\
\text { in } 2008\end{array}$ & $\begin{array}{l}\text { Dummy variable }=1 \text { if individual had a long-term disease } \\
\text { in } 2008,0 \text { otherwise (LTC) }\end{array}$ \\
\hline & $\begin{array}{l}\text { Complementary } \\
\text { health insurance } \\
\text { coverage in } 2008 \\
\left(\text { December } 31^{\text {st }}\right)\end{array}$ & $\begin{array}{l}\text { Dummy variable }=1 \text { if individual is covered by a CHI in } \\
2008,0 \text { otherwise }\end{array}$ \\
\hline & $\begin{array}{l}\text { Complementary } \\
\text { health insurance } \\
\text { coverage after } \\
\text { experiment } \\
\text { (September } 30^{\text {th }} \text {, } \\
\text { 2009) }\end{array}$ & $\begin{array}{l}\text { Dummy variable }=1 \text { if individual is covered by a } \mathrm{CHI} \\
\text { after experiment, } 0 \text { otherwise }\end{array}$ \\
\hline & $\begin{array}{l}\text { CMU-C coverage in } \\
2007 \text { (December } \\
31^{\text {st }} \text { ) }\end{array}$ & $\begin{array}{l}\text { Dummy variable }=1 \text { if individual is covered by CMU-C in } \\
2007,0 \text { otherwise }\end{array}$ \\
\hline & $\begin{array}{l}\text { Employment status } \\
\text { in } 2008 \text { (December } \\
31^{\mathrm{st}} \text { ) }\end{array}$ & $\begin{array}{l}\text { Working individual (includes occupied and unemployed } \\
\text { individuals) } \\
\text { Retired individual } \\
\text { Disabled individual }\end{array}$ \\
\hline
\end{tabular}




\section{APPENDIX B}

Table B1. Likelihood of meeting attendance (treatment group 2)

\section{Variable}

\author{
Age \\ Age $^{2}$ \\ Female \\ Employment status in 2008 \\ Working individual \\ Disabled individual \\ Retired individual \\ CMU-C coverage in 2007 \\ CHI coverage in 2008 \\ Long-term illness in 2008 \\ Ambulatory healthcare expenditures in \\ 2008 \\ $<200 €$ \\ $200 €-699 €$ \\ $700 €-1,999 €$ \\ $>=2,000 €$
}

Pseudo R ${ }^{2}$

\section{Average marginal effect}

$$
\begin{gathered}
0.009 * * *(0.0030) \\
-0.00007 * *(0.00003) \\
-0.017(0.0155) \\
\text { Ref } \\
-0.032(0.0272) \\
-0.033 *(0.0188) \\
-0.010(0.0291) \\
-0.034 * *(0.0168) \\
0.013(0.0227) \\
\\
-0.043 * *(0.0218) \\
-0.052 * *(0.0203) \\
-0.003(0.0209) \\
\text { Ref. }
\end{gathered}
$$

0.0527

$\mathbf{N}$

1,403

Note: Probit regression of the probability of attending the briefing (dummy variable: 1 individual attended the briefing; 0 otherwise). Average marginal effects are reported and standard errors are in parentheses. Statistical significance levels $*=10 \% ; * *=5 \% ; * * *=1 \%$. 


\section{APPENDIX C}

Table C1. Likelihood of returning an application form to obtain ACS (treatment group 2)

\begin{tabular}{|c|c|c|c|}
\hline & First stage & 2SLS & IV-Probit \\
\hline & Coef. & Coef. & Marginal effect \\
\hline Variable & $\begin{array}{c}\text { Meeting } \\
\text { attendance }\end{array}$ & Returned form & Returned form \\
\hline Meeting attendance & - & $0.485(0.4328)$ & $0.621(0.6165)$ \\
\hline Age & $\begin{array}{l}0.009 * * * \\
(0.0023)\end{array}$ & $\begin{array}{c}0.006 \\
(0.0047)\end{array}$ & $\begin{array}{c}0.008 \\
(0.0059)\end{array}$ \\
\hline $\mathbf{A g e}^{2}$ & $\begin{array}{l}-0.00006^{* *} \\
(0.00002)\end{array}$ & $\begin{array}{c}-0.00008^{* *} \\
(0.00004)\end{array}$ & $\begin{array}{l}-0.00009 * \\
(0.00005)\end{array}$ \\
\hline Female & $-0.016(0.0157)$ & $-0.013(0.0219)$ & $-0.016(0.0219)$ \\
\hline \multicolumn{4}{|l|}{ Employment status in 2008} \\
\hline Working & ref & ref & ref \\
\hline Retired & $-0.050(0.0432)$ & $0.159 * * *(0.0537)$ & $\begin{array}{l}0.179 * * * \\
(0.0626)\end{array}$ \\
\hline Disabled & $-0.043 *(0.0234)$ & $0.176 * * *(0.0392)$ & $\begin{array}{c}0.181^{* * *} \\
(0.0395)\end{array}$ \\
\hline CMU-C coverage in 2007 & $-0.013(0.0307)$ & $-0.043(0.0388)$ & $-0.038(0.0404)$ \\
\hline CHI coverage in 2008 & $-0.029 *(0.0172)$ & $0.046 *(0.0249)$ & $0.046 *(0.0264)$ \\
\hline $\begin{array}{l}\text { Long-term illness care in } \\
2008\end{array}$ & $0.016(0.0257)$ & $-0.012(0.0329)$ & $-0.015(0.0284)$ \\
\hline \multicolumn{4}{|l|}{$\begin{array}{l}\text { Ambulatory healthcare } \\
\text { expenditures in } 2008\end{array}$} \\
\hline$<200 €$ & $-0.047 *(0.0295)$ & $-0.051(0.0435)$ & $-0.047(0.0383)$ \\
\hline $200 €-699 €$ & $-0.055^{*}(0.0285)$ & $-0.027(0.0431)$ & $-0.016(0.0426)$ \\
\hline $700 €-1,999 €$ & $-0.004(0.0279)$ & $-0.043(0.0336)$ & $-0.029(0.0263)$ \\
\hline$>=2,000 €$ & ref & ref & ref \\
\hline \multicolumn{4}{|l|}{ Travel time } \\
\hline In minutes & $\begin{array}{l}-0.003 * * * \\
(0.0010)\end{array}$ & - & \\
\hline \multirow[t]{2}{*}{ Missing } & $0.027(0.0522)$ & - & \\
\hline & $\begin{array}{l}\text { Likelihood of } \\
\text { predicted } \\
\text { probability btw } \\
(0,1)=62.1 \%\end{array}$ & $\begin{array}{l}\text { Likelihood of } \\
\text { predicted } \\
\text { probability btw } \\
(0,1)=61.5 \%\end{array}$ & $\begin{array}{c}\text { Rho: }-0.394 \\
(0.5542) \\
\text { Prob }>\text { chi } 2= \\
0.5257\end{array}$ \\
\hline $\begin{array}{l}\text { Durbin Wu Hausman test (p } \\
\text { value) }\end{array}$ & & 0.3850 & 0.487 \\
\hline F-statistic (Weak instrument) & 8.319 & & \\
\hline $\mathbf{N}$ & 1,403 & 1,403 & 1,403 \\
\hline
\end{tabular}

Note: Robust standard errors are in parentheses. Statistical significance levels: $*=10 \%$; $* *=5 \%$; $* * *$ $=1 \%$. 
TABLES

Table I. ACS subsidy amounts

\begin{tabular}{|l|l|}
\hline Under 25 years old & $100 €$ \\
\hline $25-59$ years old & $200 €$ \\
\hline 60 and over & $400 €$ \\
\hline
\end{tabular}

Note: ACS voucher amounts per persons in the household. For example, when CHI covers a 26-year old adult and 2 children under 25 , the ACS voucher is $(200 €+2 * 100 €)=400 €$. This household could benefit from a $400 €$ discount on their annual insurance premium. 
Table II. ACS voucher amounts per capita proposed during the experiment

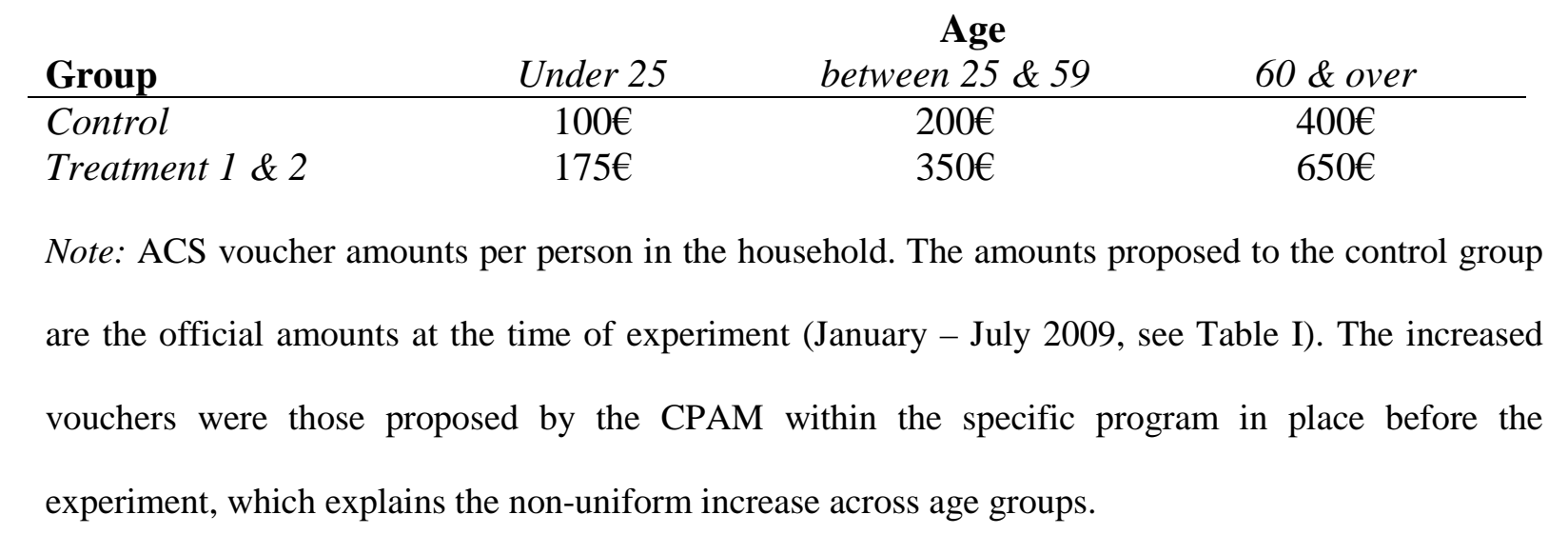


Table III. Description of the population before the experiment

\begin{tabular}{|c|c|c|c|c|c|c|c|c|}
\hline \multirow{3}{*}{ Age in 2008} & \multicolumn{8}{|c|}{ Group } \\
\hline & \multicolumn{2}{|c|}{ Control } & \multicolumn{2}{|c|}{ Treatment 1} & \multicolumn{2}{|c|}{ Treatment 2} & \multicolumn{2}{|c|}{ Total } \\
\hline & & & & & & & & \\
\hline Under 25 & 105 & $7.5 \%$ & 113 & $8.0 \%$ & 108 & $7.7 \%$ & 326 & $7.8 \%$ \\
\hline Btw. 25-59 & 1048 & $75.2 \%$ & 1056 & $74.8 \%$ & 1040 & $74.1 \%$ & 3,144 & $74.7 \%$ \\
\hline $60 \&$ over & 241 & $17.3 \%$ & 243 & $17.2 \%$ & 255 & $18.2 \%$ & 739 & $17.6 \%$ \\
\hline \multicolumn{9}{|l|}{ Sex } \\
\hline Male & 679 & $48.7 \%$ & 691 & $48.9 \%$ & 693 & $49.4 \%$ & 2,063 & $49.0 \%$ \\
\hline Female & 715 & $51.3 \%$ & 721 & $51.1 \%$ & 710 & $50.6 \%$ & 2,146 & $51.0 \%$ \\
\hline \multicolumn{9}{|c|}{ Employment status in 2008} \\
\hline Working & 845 & $60.6 \%$ & 857 & $60.7 \%$ & 865 & $61.5 \%$ & 2,567 & $61.0 \%$ \\
\hline Retired & 210 & $15.1 \%$ & 206 & $14.6 \%$ & 200 & $14.3 \%$ & 616 & $14.6 \%$ \\
\hline Disabled & 339 & $24.3 \%$ & 349 & $24.7 \%$ & 338 & $24.1 \%$ & 1,026 & $24.4 \%$ \\
\hline \multicolumn{9}{|c|}{ Healthcare expenditures in 2008} \\
\hline $0 €-199 €$ & 374 & $26.8 \%$ & 350 & $24.8 \%$ & 362 & $25.8 \%$ & 1,086 & $25.8 \%$ \\
\hline $200 €-699 €$ & 342 & $24.5 \%$ & 366 & $25.9 \%$ & 356 & $25.4 \%$ & 1,064 & $25.3 \%$ \\
\hline $700 €-1,999 €$ & 339 & $24.3 \%$ & 334 & $23.7 \%$ & 358 & $25.5 \%$ & 1,031 & $24.5 \%$ \\
\hline$>=2,000 €$ & 339 & $24.3 \%$ & 362 & $25.6 \%$ & 327 & $23.3 \%$ & 1,028 & $24.4 \%$ \\
\hline \multicolumn{9}{|c|}{ Long-term illness in 2008} \\
\hline No & 1,009 & $72.4 \%$ & 1,014 & $71.8 \%$ & 996 & $71.0 \%$ & 3,019 & $88.4 \%$ \\
\hline Yes & 385 & $27.6 \%$ & 398 & $28.2 \%$ & 407 & $29.0 \%$ & 1,190 & $28.3 \%$ \\
\hline \multicolumn{9}{|c|}{ CHI coverage in 2008} \\
\hline No & 467 & $33.5 \%$ & 477 & $33.8 \%$ & 480 & $34.2 \%$ & 1,424 & $33.8 \%$ \\
\hline Yes & 927 & $66.5 \%$ & 935 & $66.2 \%$ & 923 & $65.8 \%$ & 2,785 & $66.2 \%$ \\
\hline \multicolumn{9}{|c|}{ CMU-C coverage in 2007} \\
\hline No & 1,296 & $93.0 \%$ & 1,312 & $92.9 \%$ & 1,312 & $93.5 \%$ & 3,920 & $93.1 \%$ \\
\hline Yes & 98 & $7.0 \%$ & 100 & $7.1 \%$ & 91 & $6.5 \%$ & 289 & $6.9 \%$ \\
\hline Total & 1,394 & $100.0 \%$ & 1,412 & $100.0 \%$ & 1,403 & $100.0 \%$ & 4,209 & $100.0 \%$ \\
\hline
\end{tabular}

Note: Descriptive statistics of the individuals before the beginning of the experiment in January 2009 
Table IV. Returned ACS application forms

\section{Completed forms $\quad 95 \%$ C.I. Number of \\ individuals}

$\begin{array}{lrrrrr}\text { Control } & 222 & 15.9 \% & (14.0 \% ; 17.8 \%) & 1,394 & 100.0 \% \\ \text { Treatment 1 } & 262 & 18.6 \% & (16.5 \% ; 20.6 \%) & 1,412 & 100.0 \% \\ \text { Treatment 2 } & 217 & 15.5 \% & (13.6 \% ; 1.4 \%) & 1,403 & 100.0 \% \\ \begin{array}{l}\text { Of which: } \\ \text { with meeting }\end{array} & 35 & 28.0 \% & (20.0 \% ; 36.0 \%) & & \\ \text { without meeting } & 182 & 14.2 \% & (12.3 \% ; 16.2 \%) & 1,278 & 100.0 \% \\ \text { Total } & 701 & 16.7 \% & (15.5 \% ; 17.8 \%) & 4,209 & 100.0 \% \\ & & & & \end{array}$

Note: Sample of the experimented population. 
Table V. The voucher amount elasticity of ACS demand

Returned form
Proportion
Control Treatment 1

Elasticity (95\% C.I.)

$15.9 \%$

$18.6 \%$

0.22
$(-0.01 ; 0.49)$

$15 \%$

$16.4 \%$

$19 \%$

$$
\begin{gathered}
0.23^{*} \\
(-0.16 ; 0.76) \\
0.21 \\
(-0.06 ; 0.55)
\end{gathered}
$$

ACS notification

$\begin{array}{ccc}\text { Proportion } & \text { Elasticity } \\ \text { Control } & \text { Treatment } 1 & (95 \% \text { C. I. })\end{array}$

$7.9 \% \quad 10.8 \%$

0.49

$(0.11 ; 0.96)$

\section{in 2008}

Yes
$7.3 \% \quad 10.1 \%$

$8.2 \%$

$11.1 \%$
0.51

$(-0.12 ; 1.47)$

0.48

$(-0.03 ; 1.06)$

Note: The elasticity is calculated as the ratio of the growth rate in the probability of returning an application form (to obtain ACS) between the control and treatment 1 groups, on the one hand, and the growth rate in the voucher amount between the national and increased levels for those aged up to 60 (the rate being slightly lower for those over 60) on the other. 
Table VI. ACS agreements

$\begin{array}{cc}\text { Number of } & \begin{array}{c}\% \text { in relation } \\ \text { to the total } \\ \text { number }\end{array} \\ \text { agreements } & \begin{array}{c}\text { number of } \\ \text { individuals }\end{array}\end{array}$

$\begin{array}{lrc}\text { Control } & 110 & 7.9 \% \\ \text { Treatment 1 } & 152 & 10.8 \% \\ \text { Treatment 2 } & 125 & 8.9 \% \\ \text { Attended the meeting } & 22 & 17.6 \% \\ \text { No meeting } & 103 & 8.1 \% \\ \text { Total } & 387 & 9.2 \%\end{array}$

C.I. $95 \%$

$\begin{array}{cc}(6.5 \% ; 9.3 \%) & 49.6 \% \\ (9.1 \% ; 12.4 \%) & 58.0 \% \\ (7.4 \% ; 10.4 \%) & 57.6 \% \\ (10.8 \% ; 24.4 \%) & 62.9 \% \\ (6.6 \% ; 9.6 \%) & 56.6 \% \\ (8.3 \% ; 10.1 \%) & 55.2 \%\end{array}$

returned

forms
C.I. $95 \%$

to the total

number of

application

$(42.9 \% ; 56.2 \%)$

$(52.0 \% ; 64.0 \%)$

$(51.0 \% ; 64.2 \%)$

$(46.0 \% ; 79.6 \%)$

$(49.3 \% ; 63.9 \%)$

$(51.5 \% ; 58.9 \%)$

Note: Number of ACS agreements by group and their proportion in relation to the total number of individuals included in the experiment and the total number of completed application forms. 
Table VII. Cases of ACS refusal

\begin{tabular}{|c|c|c|}
\hline \multicolumn{3}{|c|}{ CMU-C agreement } \\
\hline Number & $\%$ in & $\%$ in \\
\hline & relation to & relation to \\
\hline & $\begin{array}{l}\text { the total } \\
\text { number of }\end{array}$ & $\begin{array}{l}\text { the total } \\
\text { number of }\end{array}$ \\
\hline & individuals & $\begin{array}{l}\text { completed } \\
\text { application } \\
\text { forms }\end{array}$ \\
\hline
\end{tabular}

\begin{tabular}{|c|c|c|}
\hline Resou & es above up & per limit \\
\hline Number & $\%$ in & $\%$ in \\
\hline & relation to & relation to \\
\hline & the total & the total \\
\hline & $\begin{array}{l}\text { number of } \\
\text { individuals }\end{array}$ & $\begin{array}{l}\text { number of } \\
\text { completed }\end{array}$ \\
\hline & & $\begin{array}{c}\text { application } \\
\text { forms }\end{array}$ \\
\hline
\end{tabular}

$\begin{array}{lcccccc}\text { Control } & 25 & 1.8 \% & 11.3 \% & 87 & 6.2 \% & 39.1 \% \\ \text { Treatment 1 } & 25 & 1.8 \% & 9.5 \% & 85 & 6.0 \% & 32.5 \% \\ \text { Treatment 2 } & 21 & 1.5 \% & 9.7 \% & 71 & 5.1 \% & 32.7 \% \\ \begin{array}{l}\text { Attended the } \\ \text { meeting }\end{array} & 2 & 1.6 \% & 5.7 \% & 11 & 8.8 \% & 31.4 \% \\ \text { No meeting } & 19 & 1.5 \% & 10.4 \% & 60 & 4.7 \% & 33.0 \% \\ \text { Total } & 71 & 1.7 \% & 10.1 \% & 241 & 5.8 \% & 34.7 \%\end{array}$

Note: The number of CMU-C agreements and the number of refusals due to resources above the limit of eligibility, and the corresponding percentages in relation to the total number of individuals and all completed application forms. 
Table VIII. Likelihood of ACS take-up

Variable

\section{Group}

Control

Treatment 1

Treatment 2

Age

Age $^{2}$

Female

Employment status in 2008

Working individual

Disabled individual

Retired individual

CMU-C coverage in 2007

CHI coverage in 2008

Long-term illness in 2008

Ambulatory healthcare expenditures in

2008

$<200 €$

$200 €-699 €$

$700 €-1,999 €$

$>=2,000 €$

Pseudo R $\mathbf{R}^{2}$

$\mathbf{N}$

\section{Average marginal effect}

$$
\begin{gathered}
\text { Ref. } \\
0.025 *(0.0139) \\
-0.004(0.0137) \\
0.012 * * *(0.0021) \\
-0.0001 * * *(0.0002) \\
-0.026 * *(0.0115) \\
\text { Ref } \\
0.154 * *(0.0342) \\
0.152 * * *(0.0187) \\
0.028(0.0236) \\
0.017(0.1187) \\
-0.007(0.0161) \\
\\
-0.054 * *(0.0177) \\
-0.007(0.0184) \\
0.011(0.0167) \\
\text { Ref. }
\end{gathered}
$$

0.0613

4,209

Note: Probit regression of the probability of ACS take-up (dummy variable: 1 individual returned an application form; 0 otherwise). Average marginal effects are reported and standard errors are in parentheses. Statistical significance levels $*=10 \% ; * *=5 \% ; * * *=1 \%$. 
Table IX. Likelihood of returning an application form to obtain ACS (treatment group 2)

\begin{tabular}{lc|} 
& Probit \\
\hline Variables & $\begin{array}{c}\text { Average marginal } \\
\text { effect. }\end{array}$ \\
\hline Meeting attendance & $0.118^{* * *}(0.0386)$ \\
Age & $0.011^{* * *}(0.0038)$ \\
Age & $-0.0001^{* * *}(0.00004)$ \\
Female & $-0.021(0.0191)$ \\
Employment status in 2008 & ref \\
Working & $0.159^{* * *}(0.0592)$ \\
Retired & $0.165 * * *(0.0330)$ \\
Disabled & $-0.041(0.0348)$ \\
CMU-C coverage in 2007 & $0.035^{*}(0.0192)$ \\
CHI coverage in 2008 & $-0.009(0.0269)$ \\
Long-term illness care in 2008 & $-0.060 * *(0.0284)$ \\
Ambulatory healthcare expenditures in 2008 & $-0.033(0.0298)$ \\
< 200€ & $-0.029(0.0254)$ \\
$200 €-699 €$ & ref \\
$700 €-1,999 €$ & \\
$>=2,000 €$ & 0.0826 \\
Pseudo R & - \\
N & 1,403
\end{tabular}

Note: Standard errors are in parentheses. Statistical significance levels: $*=10 \% ; * *=5 \%$; $* * *=1 \%$. 